\title{
A rare case of primary extramedullary intradural and extradural malignant melanoma of cervical spine
}

\section{Servikal omurgada seyrek görülen birincil ekstramedüller intradural ve ekstradural malign melanom}

Hakija BEČULIĆ ${ }^{1}$, Rasim SKOMORAC ${ }^{1}$, Aldin JUSIĆ ${ }^{1}$, Alma MEKIĆ-ABAZOVIĆ ${ }^{2}$, Fahrudin ALIĆ ${ }^{1}$, Jasminka Mustadenagić-MUJANOVIĆ ${ }^{3}$, Alma EFENDIĆ ${ }^{4}$, Nedim BARUČIJA ${ }^{5}$

\section{ABSTRACT}

In this paper, an interesting and a very rare case of primary spinal cord malignant melanoma which was diagnosed according to clinical, neuroradiological and histopathological criteria was presented. Surgical resection is the preferred treatment for these tumors and leads to the regression of neurological symptoms and improvement of the quality of life. The prognosis is related to the patient's age, well-defined borders of the tumor and the absence of dissemination or local extension at the time of diagnosis. In our case, the tumor was resected totally. During followup period, he developed pneumonia and died one month after the surgery.

Key words: Primary spinal melanoma, surgery, tumor
Öz

Bu makalede klinik, nöroradyolojik ve histopatolojik kriterlere göre tanısı konulan spinal kordun çok ender izlenen primer malign melanomu vakası sunulmuştur. Bu tümörler için cerrahi rezeksiyon tercih edilen tedavi şeklidir ve nörolojik semptomlarda gerileme ve yaşam kalitesinde iyileşme sağlanır. Prognoz hastanın yaşına, iyi tanımlanmış tümör sınırlarına ve tanısı konulduğu zaman lokal uzanımı ve yayılımının olmamasına bağlıdır. Olgumuzda tümör tamamen çıkartıldı. Takip döneminde pnömoni gelişen hasta cerrahiden 1 ay sonra kaybedildi.

Anahtar kelimeler: Spinal kordun primer melanoması, cerrahi, tümör

\section{INTRODUCTION}

Primary melanomas located in the central nervous system (CNS) are extremely rare and constitute $1 \%$ of all cases of melanomas, while spinal location is even less frequent ${ }^{1,2}$. Primary spinal melanoma was first reported by Hirschberg in 1906, and accounts for $38 \%$ of all primary CNS melanomas ${ }^{3}$. It occurs most frequently in the thoracic segment (42.3\%), followed by the cervical $(34.6 \%)$, thoracolumbar $(11.5 \%)$, cervicothoracic (7.7\%) and the lumbar (3.8\%) segments ${ }^{4}$. The primary intradural extramedullary malignant melanoma of the cervical spine is extremely rare. In the English literature only 2 cases with primary intradural extramedullary malignant melanoma of the cervical spine, and only 3 cases of primary malignant melanoma arising from cervical nerve roots have been reported ${ }^{5}$. Melanoma originates from melanotic cells of the leptomeninges and mimics the general appearance of other nerve sheath tumors or meningiomas 5 . In MRI (Magnetic Resonance Imaging) contrast scans a typical tumor gives hyperintense signals in $\mathrm{T} 1$ and hypointense ones in T25-7. The majority of patients will have back pain, and typically progressive weakness for weeks or months or asymmetric myelopathic symptoms ${ }^{7}$. 
We presented an interesting case with a verified primary spinal malignant melanoma of the cervical spine. Primary spinal cord melanoma was confirmed according to clinical, diagnostic and histopathologic criteria.

\section{CASE REPORT}

A 54-year-old male, alcohol abuser, was admitted to the Department of Neurology Cantonal Hospital Zenica with cervical pain and quadriparesis which was progressing during the previous four months.

On admission, the patient was suffering from paresis of the upper and lower limbs, located mainly in the right extremities, with accompanying hypoesthesia below $\mathrm{C} 5$ level and right lower cranial nerve palsies (IX-XII). His symptoms had progressively worsened. A careful general physical examination did not reveal any lymphadenopathy, organomegaly or cutaneous lesions. Laboratory tests showed normal values (WBC: $8.6 \times 10^{9} / \mathrm{L} ; \mathrm{RBC} 4.56 \times 10^{12} / \mathrm{L} ; \mathrm{Hgb}: 14.9 \mathrm{~g} / \mathrm{dL}$; Hmt:0.43 L/L; MCV: 94.6 fL; MCH: 32.7 pg; MCHC: 34.6 g/dL; RDW: 14.1 CV\%; PLT:305 x10\%/L; MPV: 9.5 fL; Glucose: $6.1 \mathrm{mmol} / \mathrm{L}$; Urea: $11.8 \mathrm{mmol} / \mathrm{L}$; Creatinine: 97 umol/L; Na: 139 mmol/L; K: 4.4 mmol/L; Cl: $101 \mathrm{mmol} / \mathrm{L})$.

Magnetic resonance imaging (MRI) of the cervical spine showed compressive intradural, extramedullar mass lesion on the $\mathrm{C} 5$ level, showing post-contrast intensification. MRI suggested schwannoma or meningioma (Figure 1). MRI of the brain and brainstem was normal.

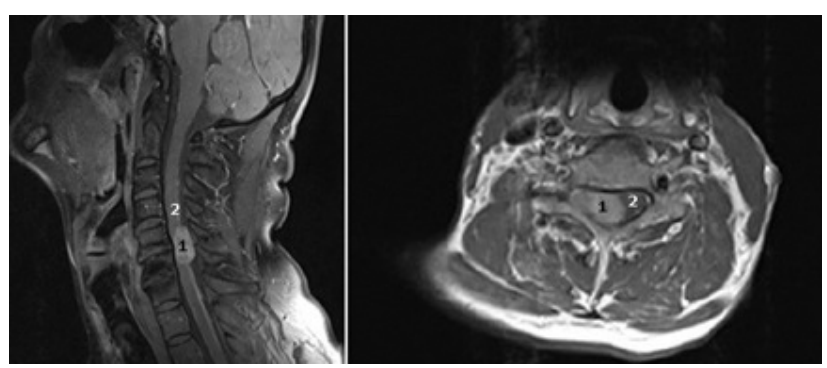

Figure 1. Magnetic resonance imaging (MRI) of cervical spinecompressive extramedullar intra- and extradural mass lesion on the C5 level with post-contrast intensification: 1-tumor; 2-spinal cord.
The patient was amenable for surgical treatment. We performed an uncomplicated C5/C6 laminectomy. After widely opening of the dura, a visibly swollen area of the spinal cord was identified and the tumor was exposed which was firm, black and hypervascularized (Figure 2). Tumor compressed the medulla, invaded the dura and C5 nerve root with significant extradural part of tumor. Tumor was resected in pieces (intra and extradural part) and sent for histopathological examination. Decompression of the spinal cord was achieved by total resection of the tumor (Figure 3). C5 nerve root was preserved. Surgery was followed by the improvement of motor function.

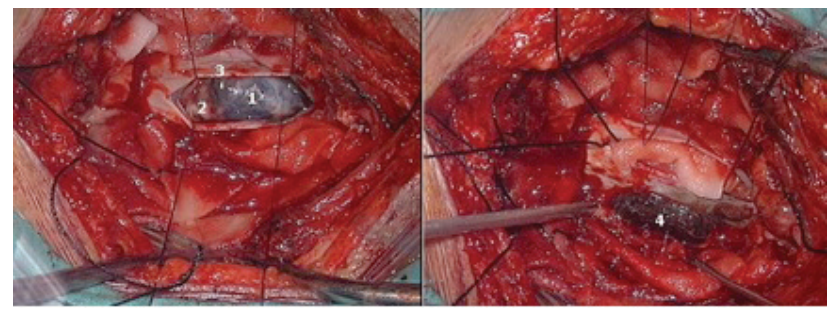

Figure 2. Extramedullar, intradural and extradural primary malignant melanoma of the cervical spine: 1-intradural extramedullar part of tumor; 2-compressed spinal cord; 3-dura; extradural part of tumor.

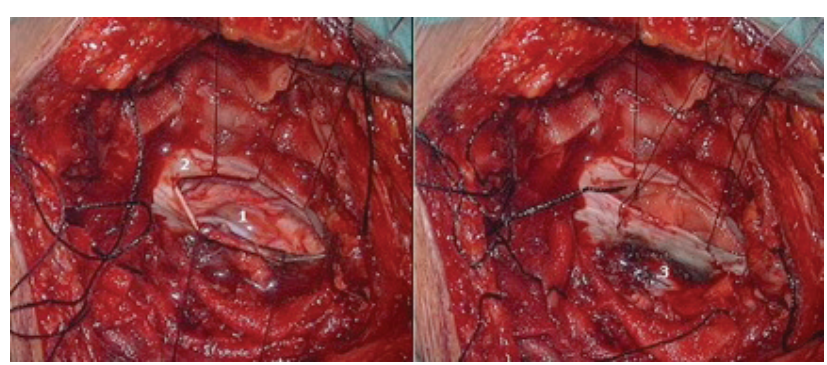

Figure 3. Cervical part of spinal cord after tumor resection: 1-decompressed spinal cord; 2-dura; 3-excized dura with extradural part of tumor.

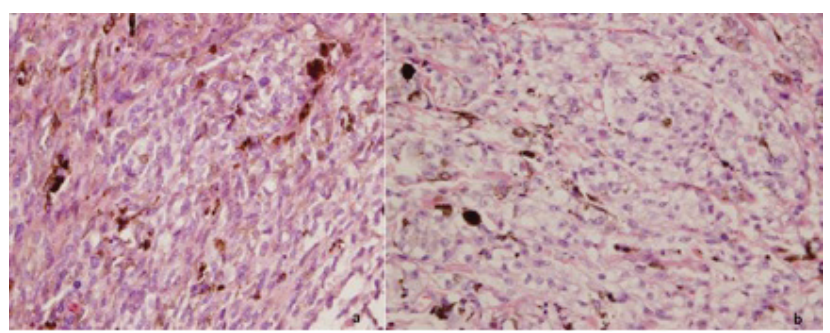

Figure 4. Spinal malignant melanoma (HE, 40x): a) Spindle cell component of tumor; b) Epithelial component of tumor. 


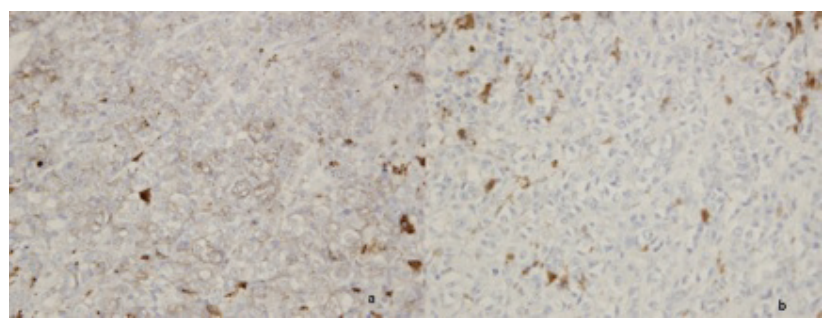

Figure 5. Imunohistochemical analysis of spinal malignant melanoma: a) positivity of tumor for HMB-45 (40x); b) positivity of tumor for Melan A (40x).

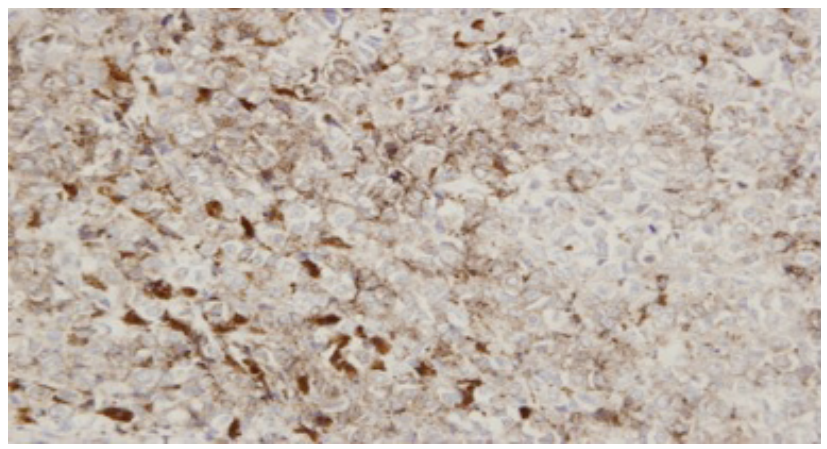

Figure 6. Imunohistochemical analysis of spinal malignant melanoma tumor negative for GFAP, tumor cells contain melanin pigment in citoplazma (40x).

Histopathological examination showed the presence of a malignant melanoma. Highly cellular tumor composed of spindle, epithelioid, and pleomorphic cells with abundant cytoplasm containing melanin deposits (Figure 4). Immunohistochemical analysis showed tumor cells positively stained with human melanoma black-45 (HMB-45) and Melan A (Figure 5). Tumor cells were negative for glial fibrillary acidic protein (GFAP). Tumor cells contained melanin pigment in cytoplasm (Figure 6).

The patient underwent other radiological studies of the head and body, as well as dermatologic and ocular examinations, which did not reveal any other foci of melanoma or metastatic disease.

On the 6-th postoperative day the patient was transferred to the Department of Otorinolaryngology because of symptomatic dysphagia for further diagnostic evaluation and treatment. Copious purulent content, which was found during directoscopy of the meso/hypopharynx, was fully evacuated. In the culture of the throat swab Klebsiella pneumoniae was isolated. Examination didn't disclose any expansive process in the lumen of the meso/hypopharynx or in the esophagus. Tracheotomy was done. Despite antibiotic and supportive therapies his general condition gradually deteriorated, he developed pneumonia and died one month later.

\section{DISCUSSION}

Primary melanomas located in the central nervous system (CNS) are rarely seen and constitute $1 \%$ of all cases of melanomas, while spinal location is even less frequent ${ }^{1,2}$. Primary spinal melanoma was first reported by Hirschberg in 1906, and accounts for $38 \%$ of all primary CNS melanomas ${ }^{3}$. Since 1906 only 40 cases of primary melanoma in spinal cord have been reported in literature. Primary malignant melanoma of the spinal cord is a very rare entity occurring most often in the middle or lower thoracic cord ${ }^{1-5}$. Only nine tumors were located in cervical part of the spinal cord6. Primary pigmented tumors of the CNS are rare and include melanotic schwannoma, meningeal melanocytoma, blue nevus of the CNS and primary melanoma ${ }^{3,6,7}$. Primary melanoma in the CNS may originate from melanoblasts accompanying the pial sheaths of vascular bundles or from neuroectodermal rest cells during embryogenesis ${ }^{1,2,7}$.

The tumor has an equal male/female ratio and occurs commonly in the 5 -th decade of life with an age range of 20 to 80 years 8 . Our case was 54 years old.

Current WHO classification divides primary melanocytic lesions of the CNS into diffuse melanocytosis, melanocytoma, meningeal melanomatosis and malignant melanoma. Among those lesions, primary malignant melanoma of the CNS accounts for only $1 \%$ of all melanoma cases ${ }^{2}$.

According to the Hayward classification, the diagnosis of primary spinal cord melanoma is based on absence of melanoma outside the CNS, and in other sites in the CNS in addition of histological confirmation of melanoma. In the case in question, additional diagnostic tests did not show any focus of melanoma. We 
did not perform positron emission tomography (PET) for technical reasons.

Clinical symptoms are nonspecific ${ }^{9,10}$. The presenting symptoms of this lesion are predominantly those of spinal cord compression ${ }^{2,3,6}$. The majority of the patients will have back pain, and typically there may be progressive weakness for weeks or months or asymmetric myelopathic symptoms. In our case, the patient had symptoms due to spinal cord compression.

At present, MR imaging is the method of choice in the diagnosis of spinal cord tumors, but discrimination between tumors based on their morphologic or signal intensity characteristics at MR imaging remains difficult ${ }^{3}$.

The primary extradural spinal melanomas are extremely uncommon tumors and they have to be differentiated from other extradural lesions like meningiomas, schwannomas, meningeal melanocytomas and vascular malformations such as cavernous hemangiomas ${ }^{11}$. The primary malignant melanomas of spinal cord are rare tumors, but the primary intradural extramedullary malignant melanoma in cervical spine is extremely rare. In the English literature only 2 cases have been reported. In addition, in the English literature only 3 cases of the primary malignant melanoma arising from cervical nerve root have been reported ${ }^{5}$. In available literature we did not find a case with extramedullary intra- and extradural primary cervical spinal melanoma which invaded the cervical nerve root.

Primary CNS melanomas metastasize within CNS, mainly in their primary sites ${ }^{9}$. Primary spinal melanoma exhibits slow progression and the tumor is less aggressive than the more common melanoma of the skin with metastases to the CNS. Metastatic melanomas grow rapidly and usually lead to fatal outcome in less than 6 months ${ }^{8-12}$.

Treatment of spinal cord malignant melanoma is difficult. The best treatment may be total surgical excision of the lesion, whenever possible and also radia- tion therapy is often recommended after surgery ${ }^{2,6,7}$. Chemotherapy may be used with radiotherapy during postoperative period ${ }^{3,6,7}$. The average time of survival after surgical treatment and chemotherapy is 6 years and 7 months $^{7-9}$.

In the case in question, we performed total surgical resection of the tumor. During the postoperative period motor function improved, but the patient showed symptoms of respiratory infection caused by Klebsiella pneumoniae. Despite antibiotic and supportive therapy his general condition gradually deteriorated, he developed pneumonia and died one month later.

\section{REFERENCE}

1. Denaro L, Pallini R, Muro L, et al. Primary hemorrhagic intramedullary melanoma. Case report with emphasis on the difficult preoperative diagnosis. J Neurosurg Sci 2007;59:181-3.

2. Farrokh D, Frasen P, Faverly D. MR findings of a primary intramedullary malignant melanoma: case report and literature review. AJNR Am J Neuroradiol 2001;22:1864-6.

3. Brad DJ, Giannini C, Scheithauer BW, Burger PC. Primary melanocytic neoplasms of CNS. Am J Surg Pathol 1999;23(7):74554.

http://dx.doi.org/10.1097/00000478-199907000-00001

4. Kim MS, Yoon DH, Shin DA. Primary spinal cord melanoma. J Korean Neurosurg Soc 2010;48:157-61.

http://dx.doi.org/10.3340/jkns.2010.48.2.157

5. Lee $\mathrm{CH}$, Moon KY, Chung CK et al. Primary intradural extramedullary melanoma of the cervical spinal cord: case report. Spine (Phila Pa 1976) 2010;35:E303-7. http://dx.doi.org/10.1097/BRS.0b013e3181ccb1b3

6. Kolasa M, Jesionek-Kupnicka D, Kordek R, Kolasa P. Primary spinal cord melanoma - a case report. Folia Neuropathol 2010;48(3):212-16.

7. Kounin GK, Romansky KV, Traykov LD, et al. Primary spinal melanoma with bilateral papilledema. Clin Neurol Neurosurg 2005;107(6):525-7.

http://dx.doi.org/10.1016/j.clineuro.2004.10.013

8. Kim MS, Yoon DH, Shin DA. Primary spinal cord melanoma. J Korean Neurosurg Soc 2010;48:157-61.

http://dx.doi.org/10.3340/jkns.2010.48.2.157

9. Hirano A, Carton CA. Primary malignant melanoma of the spinal cord. J Neurosurg 1960;17:935-44.

http://dx.doi.org/10.3171/jns.1960.17.6.0935

10. Larson T, Houser O, Onofrio B, Pieperas D. Primary spinal melanoma. J Neurosurg 1987;66:47-49. http://dx.doi.org/10.3171/jns.1987.66.1.0047

11. Jo KW, Kim SR, Kim SD, Park IS. Primary thoracic epidural melanoma: a case report. Asian Spine Journal 2010;4(1):48-51. http://dx.doi.org/10.4184/asj.2010.4.1.48

12. Cetinalp NE, Yildirim AE, Divanlioglu D, Belen D. An uncommon intramedullary tumor: primary spinal cord melanoma. Asian Spine J 2014;8(4):512-5. http://dx.doi.org/10.4184/asj.2014.8.4.512 